\title{
KEBIJAKAN HUKUM SEBAGAI ISTRUMEN PEMBANGUNAN BERWAWASAN LINGKUNGAN
}

\author{
Imam Makhali \\ Fakultas Hukum Universitas Islam Kadiri (UNISKA) \\ Jalan Sersan Suharmaji No.38 Kediri, Jawa Timur, Indonesia
}

\begin{abstract}
Environmental law and policy in Indonesia has been applied as an instrument of development of environmentally sound and sustainable from 1973 until today. But by doing so, the application of environmental law and policy are still new to the material formulation phase and yet to no actual implementation which has been promoting the creation of environmental quality, for the consideration of environmental quality is often defeated by economic considerations.
\end{abstract}

Keywords : Legal Policies, Instruments Environmentally Sound Development

\begin{abstract}
ABSTRAK
Kebijakan dan hukum lingkungan di Indonesia sudah diaplikasikan sebagai instrumen pembangunan yang berwawasan lingkungan dan berkelanjutan sejak tahun 1973 hingga saat ini . namun dengan demikian, aplikasi kebijakan dan hukum lingkungan tersebut masih baru sampai pada fase dan formulasi materi belum sampai ada pelaksanaan yang sesungguhnya yang telah mengedepankan terciptanya kualitas lingkungan hidup, sebab pertimbangan kualitas lingkungan hidup acapkali dikalahkan oleh pertimbangan ekonomi.
\end{abstract}

Kata kunci :Kebijakan Hukum, Instrumen Pembangunan Berwawasan Lingkungan 


\section{A. PENDAHULUAN}

\section{Latar Belakang Masalah}

Kebijakan hukum merupakan instrumen yang dapat berfungsi sebagi aturan atau pedoman dalam menjalankan roda pembangunan dalam suatu negara. Karena sebagai atau aturan pedoman, maka hukum dan kebijakan dapat dibedakan antar satu dengan yang lainya. Namun dengan demikian, orang acap kali merancukan antara kebijakan, kebijaksanaan dan hukum.

Pengelolaan lingkungan, kebijakan, kebijaksanaan dan hukum pada dasarnya sama sama memiliki fungsi sebagai instrumen. Dapat dicermati tehadap implementasi pembangunan khusunya pembangunan yang bewawasan lingkungan (eco devolopment) dan berkelanjutan (Sustainable Development) dalam suatu negara dengan mencermati instrumen kebijakan, kebijaksanaan dan hukum didalam bidang lingkungan disuatu negara.

Komisi dunia untuk lingungan (World Commission on Environment and Devolopment / WCED) telah mendifinisikan pembangunan berkelanjutan sebagai devolopment that meet the needs of the present withaut compromising the obility of future generations to meet their own needs" (pembangunan yang memenuhi kebutuhan masa kini tanpa mengorbankan hak pemenuhan kebutuhan generasi masa datang ) telah mengartikan pembangunan berkelanjutan sebagai perbaikan mutu kehidupan manusia dengan tetap berusaha tidak melampaui kemampuan ekositem yangmendukung kehidupan. ${ }^{37}$

Dengan demikian agar pembangunan berwawasan lingkungan dan berkelanjutan dapat diwujudkan, maka diperlukan pengintegrasian rencana dan kegiatan pengelolaan lingkungan hidup sebagai tolak ukur evaluasi keberhasilan suatu proses pembangunan. Indikator implementasi pembangunan berwawasan lingkungan dan bekelanjutan tersebut dapat

${ }^{37}$ Aninymus , Bumi Wahana, strategi menju Kehidupan yang Berkelanjutan, Jakata PT Gramedia Pustaka Utama, Terjemahan dari Caring the Eart, A Strategy for SustainableLiving. 1993. 
dicermati dari realisasi kebijakan, kebijaksanaan dan hukum lingkungan yang selama ini ditempuh dan dilaksanakan di Indonesia.

\section{Rumusan Masalah}

a. Bagaimana kebijakan hukum lingkungan setelah diimplementasikan sebagai instrumen pembangunan berwawasan lingkungan.

b. Apakah kebijakan dan hukum lingkungan sudah dilaksanakan dengan benar.

\section{Tujuan Penelitian}

a. Menelaah secara mendalam kebijakan hukum lingkungan setelah diimplementasikan sebagai instrumen pembangunan berwawasan lingkungan.

b. Mengetahui kebijakan dan hukum lingkungan sudah dilaksanakan dengan benar.

\section{B. PEMBAHASAN.}

\section{Hakekat Kebijakan dan Kebijaksanaan}

Kebijakan yang dimaksudkan adalah merupakan terjemahan dari kata Policy dalam imu administrasi, namun sering juga Policy juga diterjemahkan dengan kebijaksanaan, walaupun kata kebijaksanaan itu sendiri memiliki konotasi tersendiri.

Dalam ilmu hukum, khusunya hukum administrasi negara telah mengenal istilah kebijaksanaan sebagai suatu asas bahwa pemerintah dalam segala tindakan harus berpandangan luas dan selalu dapat menghubungkan dalam menghadapi tugasnya itu, terhadap gejala gejala masyarakat yang harus dihadapinya dan harus pandai memperhitungkan lingkungan akibat tindakan pemerintahanya itu dengan mengalihkan yang jauh kedepan.

Asas kebijaksanaan merupakan dasar dari Freies Ermessen (discretion ary power). Freies Ermessen pada hakekatnya memberikan kebebasan bertindak kepada pemerintah dalam menghadapi situasi yang 
kongkrit (casuistis) dimana aturan penyelesaianya (secara tertulis) belum ada atau aturanya sudah ada tetapi memberikan peluang bagi pemerintah untuk bertindak sendiri menyelesaikan persoalan yang sedang dihadapinya. Dengan Freies Ermessen pejabat pemerintah memiliki kewenangan memiliki kewenangan untuk menentukan (menilai) sendiri berdasarkan kepada asas kebijaksanaan, mengenai perbuatan apa yang perlu dilakukan dan yang tidak perlu dilakukan perbuatan pejabat pemerintah yang didasarkan atas kewenangan bebas tersebut bisa berupa perbuatan yang bertentangan dengan undang undang atau tidak diatur dalam undang undang, tetapi boleh untuk dilakukan jika memenuhi syarat syarat tertentu dalam arti bukan merupakan perbuatan sewenag-wenang atau penyalahgunaan wewenang (detournement de pouvoir). ${ }^{38}$

Kebijakan dalam arti policy tidak bersangkut paut dengan suatu kewenangan bebas tindaknya perbuatan yang diakukan oleh pejabat pemerintah atau tidak diaturnya perbuatan pejabat pemeritah dalam undang undang, melainkan bersangkutpaut dengan sikap dan perbuatan pemerintah demi kepentigan umum. Oleh karena itu, bedasarkan hukum administrasi negara kebijakan dalam arti Policy tidak boleh dirancukan dengan kebijkasanaan sebagai asas pijakan Freies Ermessen .

Kebijakan pemeritah dikategorikan sebagai kebijakan umum publik. Menurut Dye "Publik Policy is whotever goernments choos to do or not to do" Apayang dilakukan oleh pemerintah, Pemerintah memang melakukan banyak hal secara garis besarnya, Pemerintah mengatur masyarakat dan mengurus kepentingan masyarakat. Lebih lanjut Dye mengatakan Thus public policies may be regulative, organizational, distributive orextractive or oll these things atonce.

Dalam kaitan ini, Carl Frederich menyatakan it is essential for the policy concep that there be agoal, objective, or purpose " Hal ini berarti bahwa dalam setiap kebijaksanaan pemerintah selalu terkandung tujuan

38 Purbopranoto K. Beberapa Catatan HukumTata Pemerintahan dan Peradilan Administrasi Negara, Bandung : Alumni, 1978, hlm. 36 
yang Dye R. hendak dicapai dan sekaligus sarana yang akan digunakan untuk mencapai tujuan. Ada sebagian yang mendifinisakan polecy sebagai suatu pernyataan tentang apa yang akan diperbuat, mengenai apa, bagai mana atau pedoman didalam mengambil keputusan untuk berbuat atau tidak berbuat. ${ }^{39}$ Degan demikian, kebijakan pada dasarnya merupakan ketentuan ketentuan yang harus diadikan pedoman pegangan atau petunjuk bagi setiap usaha dan kegiatan aparatur pemerintahan, dalam rangka mencapai kelancaran dan keterpaduan dalam upaya mencapai tujuan. ${ }^{40}$ Keberhasian dari suatu kebijakan akan diukur dari beberapa jauh manfaat dalam mencapai tujuan tersebut dengan tingkat daya guna dan hasil guna yang diharapka. Namun demikian, dalam memahami kebijakan pemerintah, tidak semata mata terbatas pada tujuanya melainkan juga menyangkut norma nilai yang menjadi landasan penyusunan kebijakan, proses penyusunanya, sosialisasinya dan pelaksanaaya. ${ }^{41}$

\section{Hubungan Kebijakan dan Hukum}

Untuk kepastian bagi pelaksanaanya, kebijakan sebaiknya tertulis, kebijakan itu tertuis dalam bentuk peraturan perundang undangan dan yang tidak berbentuk peraturan perundang undangan seperti pidato dan Surat Edaran. Dengan demikian, kebijakan pemerintah bisa terdapat dalam perturan perundang undangan maupun diluar peraturan perundang undangan. Kebijakan pemerintah yang tercantum dalam peraturan perundang undagan berlaku sebagai hukum, memiliki kekuatan mengikat atau memaksa, sedangkan kebijakan yang diluar peraturan perundang undangan tidak berlaku sebagai hukum, oleh karenanya tidak memiliki kekuatan yang memaksa. ${ }^{42}$ Hal ini megandung arti bahwa mana kala

\footnotetext{
${ }^{39}$ Thomas Understanding Publik Policy, third ediion. Englewood Cliff, NJ, 1978, hlm .3

${ }^{40}$ Dye R. Thomas Understanding Publik Policy, third ediion. Englewood Cliff, NJ, 1978 hlm. 4

41 Rangkuti SS. Hukum Lingkungan dan Kebijakan Ligkungan Nasional Surabaya Airlangga University, 1996, hlm. 6

42 Soetarjono RR. Kebijakan Hukum dan Peraturan Perundang undangan di Bidang Lingkungan Hidup , 1998 , hlm. 12
} 
kebijakan pemerintah ingin diberlakukan dan mengikat berlakunya tersebut kepada masyarakat, maka kebijakan tersebut harus dimuat dalam peraturan perundang undangan. Dalam pada itu maka peraturan perundang undangan itu berfungsi sebagai instrumen bagi kebijakan pemerintah. ${ }^{43}$

Dalam hal Freies Ermessen, acap kali pejabat pemerintah merumuskan tentang tata cara penggunaan wewenangnya yang akan digunakan sebagai pedoman kerja dalam bentuk peraturan peraturan yang dipublikasikan agar diketahui dan diikuti oleh umum. Peraturan perundang undangan tesebut dapat berbentuk surat keputusan atau surat edaran dan lain sebagainya. Peraturan pejabat pemerintah yang seperti itu tidak dapat disebut atau dikategorikan sebagai hukum, karena peratuan yang dikeluarkan oleh pemerintah itu tidak memiliki wewenang legislaif yang sebenarnya, melainkan disebut perundang undangan semu (pseudo wetgiving) atau lazimnya telah disebut sebagai perturan perauran kebijaksanaan (beleidsregel, policy rule). ${ }^{44}$ Dalam hukum lingkungan, peraturan dari pejabat pemerintah yang termasuk kedalam pseudo wegiving misalnya bisa berupa Surat Edaran Menteri Negara Kependudukan dan Lingkungan Hidup No.03/ SE/MENKLH/6/1987, tanggal 5 Juni 1987 tentang Prosedur Penanggulangan.

Kasus Pencemaran dan Perusakan Lingkungan Hidup dan Surat Edaran Kepala Daerah Tingkat I Jawa Timur No 660/17439/033/1994/ tanggal 29 Oktober 1994, tentang Mekanisme Laporan Pengaduan Trjadinya kerusakan / Pencemaran. Oleh karena itu, isi kedua peraturan diatas, tidak memiliki kekuatan mengikatnya hukum, karena :

a. Surat Edaran, beserta Surat Keputusan yang dibuat atas dasar Surat Edaran tersebut, bukan merupakan peraturan perundang undangan.

\footnotetext{
${ }^{43}$ Soetaryono, RR. Kebijakan Hukum dan Peraturan Perundang undangan di Bidang Lingkungan Hidup 1998 hlm. 2

${ }^{44}$ Indroharto, Usaha Memahami Undang Undang Tentang Peradilan Tata Usaha Negara , 1991, h1m. 197.
} 
b. Kedua peraturan tersebuthanya berfungsi sebagai sarana menuju suatu kepastian dari kebijaksanaan pejabat yang bersangkutan dalam menentukan dan menerapkan tata cara penggunaan wewenangnya.

\section{Lingkup Kebijakan}

Kebijakan nasional, kebijakan internasional dan kebijakan Daerah. Kebijakan nasional merupakan kebijakan yang dikeluarkan oleh pemerintah pusat, bersifat fundamental dan strategis dalam mencapai tujuan nasional. Sedangkan kebijakan daerah adalah suatu kebijakan yang dikeluarkan oleh pemerintah daerah sebagai pelaksanaan otonomi daerah. Baik kebijakan naional maupunaerah, masing masing tedapat :

a. Kebijakan yang bersifat umum, berupa garis garis besar kebijakan.

b. mengenai pelaksanaanya, yang merupakan penjabaran terhadap kebijakan yang bersifat umum.

c. Lingkup Kebijakan Pemerintah dapat dibedakan menjadi secara teknis, yang merupaka penjabaran dari kebijakan pelaksanaan.

Kebijakan pemerintah umunya diambil antara lain :

a. Untuk mengatasi atau untuk menanggulangi permasalahan tertentu atau guna untuk mencapai tujuan tujuan tertentu atau;

b. Untuk melakanakan dan mengimplementasikan produk produk keputasan atau peraturan peraturan perundang undangan yang telah ditetapkan.

Adapun ruanglingkup terhadap kebijaksanaan pemerintah dapat ditinjau dari beberapa aspek antara lain :

a. Aspek substansi dimana dilihat dari sektor atau bidang sosial, ekonomi, udaya, administrasi, ligkungan hidup dan lain sebagainya. 
b. Aspek strata dimana kebijakan strategis kebijakan eksekutif atau kebijakan menejerialnya, danterhadap kebijakan teknis operasional. $^{45}$

c. Dilihat dariaspek status hukum : yaitu dri Undang Undangnya, Perauran Pemerintah, Keutusan Presiden, Intruksi Presiden, Keputusan Menteri, dan lain sebagainya.

\section{Realisasi Terhadap Kebijakan Lingkungan.}

Kebijakan lingkungan adalah merupakan kebijakan yang dilakukan oleh pemerintah dibidang lingungan, yang menyangkut mengenai pertanyaan apa kira kira yang ingin dicapai dalam pengelolaan lingkungan, bagai mana dan jalan apa yang perlu harus ditempuh dalam pengelolaan lingkungan, serta dengan sarana apa pengelolaan lingkungan itu dapat dilaksanakan.

Untuk menjawab pertanyaan pertanyaan tersebut perlu diketahui tempat dimana kebijakan lingkungan hidup itu dirumuskan dan ditetapkan, Kebijakan lingkungan yang termuat dalam Perundang undangan tampil kepermukaan sebagai Hukum Ligkungan. oleh karena itu, ia memiliki kekuatan hukum mengikat. Rumusan kebijakan lingkungan yang dirumuskan dan ditetapkan dalam UUD 1945 akan menjadi acuan terhadap rumusan kebijakan lingkungan yang ditetapkan dalam Garis Garis Besar Haluan Negara /GBHN. Rumusan kebijaksanan lingkunganya dirumuskan dan ditetapkan dalam GBHN yang dimat dalamTAP MPR akan menjadi acuan terhadap rumusan kebijakan lingkunganya yang ditetapkan dalam undang undang rumusan kebijakan lingkuganya ditetapkan dalam Undag undang akan menjadi acua terhadap rumusan kebijakan lingkungan yang ditetapkan dalam peraturan perturan pemeritah demikian seterusnya mengikuti tata uruan perundang undangan yang berlaku di Indonesia.

45 Soetaryono, RR. Kebijakan Hukum dan Peraturan Perundang undangan di Bidang Lingkungan Hidup ,1998, hlm. 158. 
Ditinjau dari segi lingkungan wilayah , terdapat kebijakan lingkungan nasional, tentang nasional dan Daerah. Rumusan kebijakan lingkungan yang ditetapkan dalam GBHN, UU, Peraturan Pemerintah, Keputuan Presiden dan Intruksi Menteri merupakan kebijakan lingkungan lingkup wilayah nasional, sedangkan yang temuat dalam Peraturan Pemeritah daerah (Perda) Keputusan Daerah, Intruksi Gubernur, Bupati, Walikota, merupakan kebijakan dalam lingkup daerah. Kebijakan lingkungan Internasional merupakan kebijakan yang dirumuskan dan ditetapkan dalam deklarasi dan konvensi konvensi lingkungan Internasional.

Kebijakan lingkungan dalam UUD 1945 dapat kita temukan dalam pembukaan UUD 1945 aliniea keIV yang berbunyi " kemudian dari pada untuk membentuk suatu pemeritah negara Indonesia yang melindungi segenap bangsa Indonesia dan seluruh tupah darah Indonesia ....."

Ketetuan diatas menegaskan"Kewajiban Negara" dan Tugas Pemerintah untuk melindungi segenap sumber daya lingkungan hidup untuk kebahagiaan seluruh rakyat Indoesia dan segenap umat manusia. Dengan kata lain, negara / pemerintah Indonesia harus menyelenggarakan perlindungan lingkungan hidup Indonesia dengan segenap unsur insanya “.

Pemikiran dasar tersebut diatas dirumuskan lebih konkrit dalam pasal 33 ayat 3 UUD 1945 yang menyatakan bahwa " Bumi dan air dan kekayaan alam yang terkandung didalamnya dikuasai oleh negara dipergunakan untuk sebesar besarnya kemak muran rakyat “.

Ketentuan diatas memberikan "Hak Penguasaan kepada negara, yang berarti bahwa memberikan kewenangan kepada negara untuk mengatur pola dan cara penggunaan segenap unsur unsur bersumber daya alam Indonesia dan memberikan kewajiban kepada negara untuk menggunakan bagi sebesar besarnya memakmurkan rakyat. Kebijakan lingkungan yang termuat dalam UUD 1945 merupakan landasan konstitusional, sedangkan yang termuat dalam GBHN berfungsi sebagai landasan operasional. 
Dalam GBHN yang pernah berlaku di Idonesia,kebijakan lingkungan sudah dimasukkan sejak GBHN 1973-1978,GBHN 1978-1983, GBHN, 1983-1988, GBHN, 1988-1993, GBHN 1993-1998, hingga saat ini GBHN, 1999 - 2004 berdasarkan TAP MPR no. IV / MPR/ 1999.

Kebijakan lingkungan pada BHN 1999-2004 terdapat dalam Bab IV Arah dan Kebijakan, huruf H. Sumber Daya Alam dan Lingkugan Hidup . Namun demikian, dalam GBHN 1999 - 2004 ini, perihal likugan hidup sudah ditegaskan sebagai salah satu visi dan misi GBHN; dan dalam huruf B. Ekonomi sudah dimasukan peran lingkungan hidup. Visi dan misi ini merupakan landasan, pedoman dan arah GBHN kepada segenap lembaga tinggi negara dan rakyat Indonesia.

Visi dan misi GBHN 1999-2004 yang terkait degan lingkungan hidup adalah sebagai berikut : visi GBHN : “ terwujudnya masyarakat Indonesia yang damai, demokratis keadilan berdaya saing cinta tanah air, berkeadaan hukum dan lingkungan menguasai ilmu pengetahuan dan teknologi, ...".

Misi GBHN khusunya angka 7 Pemberdayaan masyarakat dan seluruh kekuatan ekonomi nasional, terutama pengusaha kecil, dan koperasi, dengan mengembangkan sistem ekonomi kerakyatan yang bertumpu pada mekanisme pasar yang berkeadilan berbasis pada sumber daya alam dan sumber daya manusia yang produktif, mandiri, maju, berdaya saing, berwawasan lingkungan dan kelanjutan.

Bab IV huruf H. GBHN; Sumber Daya Alam dan Lingkungan Hidup.

a. Mengelola sumber daya alam dan memelihara daya dukungnya agar bermanfaat bagi peningkatan kesejahteraan rakyat dari generasi ke generasi;

b. Meningkatkan pemanfaatan potensi sumber daya alam dan lingkungan hidup dengan melakukan konservasi, rehabilitasi dan penghematan penggunaan, dengan menerapkan teknologi lingkungan; 
c. Mendelegasikan secara bertahap wewenang perintah pusat kepada pemerintah Daerah dan pelakanaan pengelolaan suberdaya alam secara selektif dan pemeliharaan lingkungan hidup sehigga kualitas ekonomi tetap terjaga, yang diatur dengan undang undang;

d. Mendaya gunaka sumber daya alam untuk sebesar besarnya kemakmuran rakyat dengan memperhatikan kelestarian fungsi dan keseimbangan lingkungan hidup, pembangunan dan berkelanjutan, kepentingan ekonomi dan budaya masyarakat lokal, serta penataan ruang, yang pengusahanya diaur degan undang undang; dan

e. Menerapkan indikator indikator yang memungkinkan pelestarian kemampuan keterbaharuan dalam pengelolaan sumber daya alam yang dapat diperbaharui untuk mencegah kerusakan yang tidak dapat balik.

Bab V kaedah Pelaksanaan GBHN, GBHN tahun 1999-2004 yang ditetapkan oleh MPR dalam sidang umum MPR 1999, harus menjadi arah peyelenggaraan negara baik lembaga lembaga tinggi negara dan segenap rakyat Indonesia. Untuk itu perlu ditetapan kaedah kaedah pelaksanaanya sebagai berikut

a. Presiden selaku kepala pemerintahan negara, menjalankan tugas penyelenggaraan pemeritah negara, bekewajiban untuk mengerahkan semua potensi dan kekuatan pemerintahan dalam pelaksanaan dan menggendalikan pembangunan nasional

b. Dewan Perwakilan Rakyat, Mahkamah Agung, Badan Pengawas Keuangan, dan Dewan Pertimbangan Agung, berkewajiban melaksanakan GBHN ini sesuai dengan fungsi, tugas dan wewenangnya berdasarkan UUD 1945;

c. Semua lembaga tinggi negara berkewajiban menyampaikan laporan pelaksanaan GBHN dalam sidang tahunan MPR sesuai 
dengan tugas, fungsi dan wewenangnya sesuai dengan Undang Undang Dasar 1945;

d. Dalam pelaksanaanya Garis Garis Besar Haluan Negara telah dituangkan Program Pembangunan Nasional Lima Tahun (Propenas) yang telah memuat semua uraian kebijakan secara rinci dan terukur yang telah ditetapkan oleh Presiden sebagai eksekutif bersama sama dengan Dewan Perwakilan Rakyat; dan

e. Semua Program Pembangunan Nasional yang lima tahunan PROPENAS dirinci dala rencana pemangunan tahun REPETA yang memuat anggaran Pendapatan dan Beanja Negara APBN dantelah ditetapkan oleh Presidn dan Dewan Perwakilan Rakyat.

Ditinjau dari isi Garis Garis Besar Haluan Negara tersebut dapat diketahui kebijakan lingungan rakyat Indonesia melalui wakil wakilnya dalam Majelis Permusyawaratan Rakyat terhadap Pembangunan yang berwawasan linkungan dan yang berkelanjutan. Mengenai kebijakan lingkungan hidup yang tercantum dalam Garis Garis Besar Haluan Negara tersebut telah merupakan kehendak politik yang sangat perlu diaksanakan, tidak hanya oleh Pemerintah namun juga oleh Lembaga Lembaga Tinggi Negara yang laiya. Inilah salah satu perubahan yang terpenting dari GBHN 1999- 2004. Perubahan yang dimaksudkan adalah digunakanya istilah Repelita.

Adapun isi GBHN 1999-2004 telah mengantisipasi terhadap berlakunya Undang-undang No 22 Tahun 1999 tentang Pemeritahan Daerah yang menetapkan lingkungan hidup sebagai bagian dari otonomi daerah, sebagai mana dicantumkan dalam Pasal 10 dan Pasal 11 (2) yang berbunyi :

1. Daerah berwenang mengelola sumber daya nasional yang tesedia diwilayahnya dan bertanggung jawab memelihara kelestarian lingkungan sesuai dengan peraturan perundang undangan.

2. Kewenangan Daerah diwilayah Laut, sebagai mana dimaksudkan dalam Pasal 3 , meliputi:

a. Eksplorasi, eksplotasi, konservasi dan pengelolaan kekayaan laut sebatas wilayah tersebut 
b. Pengaturan kepentigan administratif

c. Pengaturan tata ruang;

d. Penegakan hukum tehadap peratura yang dikeluarkan daerah atau yang dilimpahkan kewenanganya oleh pemerintah ; dan

e. Bantuan penegakan keamanan dan kedaulatan negara.

3. Kewenangan Daerah Kabupaten dan daerah kota diwilayah laut, sebagai mana dimaksudkan ayat (2) adalah sejauh sepertiga dari batas laut Daerah Provinsi;dan

4. Pengaturan lebih lanjut mengenai ketentuan sebagaimana dimaksud pada ayat (2) ditetapkan dengan Peraturan Pemerintah.

Selanjutnya pada Pasal 11 berbunyi :

1. Kewenangan Daerah Kabupaten dan daerah Kota mencakup semua kewenangan pemerintahan selain kewenangan yang dikecualikan dalam Pasal 7 dan yang diatur dalam Pasal 9.

2. Bidang pemerintahan yang wajib dilaksanakan oleh daerah kabupaten dan daerah Kota meliputi pekerjaan umum kesehatan, pendidikan dan kebudayaan pertanian, perhubungan, industri dan perdagangan, penanaman modal, lingkungan hidup, pertanahan, koperasi dan tenaga kerja.

Lingkungan hidup sebagai bagian dari kewenagnan (otonomi) daerah akan memberikan suatu dampak perubahan terhadap kebijakan pengelolaan lingkungan dari yang semua kebijakan lingkungan yang cendrung dengan pendekatan top down (atas /pengausaan/ pusat) akan dapat beralih pada kebijakan lingkungan yang bottom up dari bawah/raktyat/ daerah). Keterbukaan lingkungan daerah diharapkan akan dapat betul betul mengakomodasi aspirasi masyarakat (rakyat) dan kepentingan lingkungan daerah yang urgen untuk ditangani, sehingga pendekatan bottom up menjadi kenyataan, bukan hanya sekedar retorika. UU No. 22 Tahun 1999 telah memberikan landasah hukum bagi terselenggaranya pendekatan battom up dalam pengelolaan lingkungan melalui dalam pengelolaan lingkungan melalui pemberdayaan peran serta masyarakat sebagai mana dimuat dalam Pasal 110 yang berbunyi :

"Pemerintah Daerah Kabupaten dan atau pihak ketiga yang merencanakan pembangunan bagian wilayah Desa menjadi wilayah permukinan, industri dan jasa wajib mengikut sertakan Pemerintah 
Desa dan Badan Perwakian Desa dalam Perencanaa, pelaksanaan dan Pengawasan.". 46

Dampak perubahan penting lainya, dengan berlakunya Undangundnag Nomor 22 Tahun 1999 adalah dimungkinkan yang eksploitasi sumber daya alam di daerah untuk memperoleh pendapatan asli daerah (PAD) yang sebesar besarnya. Selain itu pula akan mungkin terjadi konflik kepentingan antar Kabupaten dalam pengelolaan lingkungan lintas wilayah Kabupaten. Salah satu contohnya adalah apabila telah terdapat suatu industri / pabrik diwilayah kabupaten lain Kabupaten lain yang lingukungan wilayahnya tercemar atau rusak akibat kegiatan industri diwilayah kabupaten A tidak akan mau menerima begitu saja; I mungkin akan menuntut kepada industri yang menyebabkan pencemaran dan perusakan lingkungan atau; setidak tidaknya ia (kabupaten lain) akan protes kepada Kabupaten A untuk menerapkan kebijakan penegakan hukum lingkungan.

Berdasarkan uraian diatas, diperlakukan kesiapan sumber daya manusia (SDM) yang mampu melakukan pengelolaan lingkungan dengan tepat dan benar, dan memilki moral, etika dan kesadaran hukum dan lingkungan, sehingga mampu melakukan pengelolaan lingkungan hidup secara benar dan berpegang pada asas asas kebijakan lingkungan yang tepat. Hanya SDM dengan qualifikasi seperti itulah akan didapatkan suatu kebijakan lingkungan yang baik mulai dari fase perumusan kebijakanya sampai pada pelaksanaan/ penerapan serta evaluasi keberhasilanya yang berwawasan lingkungan dan berkelanjutan. Hal ini untuk menghindari efek sampingan dari berlakunya UU no 22 Tahun1999 yang dimungkinkan Pemerintah daerah mengekplotasi sumberdya alamnya hanya untuk mengejar pendapatan asli dareah yang setinggi tingginya tanpa memperdulikan daya dukung lingkunganya.

\footnotetext{
${ }^{46}$ Lihat dalam Penjelasan Pasal 110 menjelaskan: Pemerintah Desa yang tidak diikut sertakan dalam kegiatan dimaksud berhak menolak pembangunan tersebut.
} 
Beberapa asas kebijakan lingkunga yang dikenal dan berlaku di Belanda dapat juga dijadikan acuan kebijakan pengelolaan lingkungan di Indonesia, yang meliputi :
a. Asas penangguangan pada sumbernya
b. Sarana praktis yang terbaik
c. Prinsip pencemar membayar
d. Prinsip cegah tangkal
e. Prinsip perbedaan regional
f. Beban pembuktian terbalik.

\section{Implementasi Kebijakan dan Hukum Lingkungan.}

Kebijakan lingkungan di Indonesia sejak tahun 1973 sudah dapat dijadikan indikator suatu negara yang menerapkan dan telah melaksanakan pembangunan yang berwawasan lingkungan dan berkelanjutan, sebagaimana (TAP MPR No IV /MPR/1973, tentang GBHN Bab II huruf B ayat 10, Replita II Buku I bab IV) demikian pula, dalam tatara hukum lingkungan, pembangunan yang berwawasan lingkungan dan berkelanjutan, sudah dilaksanakan dan diterapkan di Indonesia sejak berlakunya UU no 4 Tahun 1982 tentang Ketentuan ketentuan Pokok Pengelolaan Lingkunga Hidup. Asas, tujuan dan dasar Pengelolaan lingkungan menurut Undang-undang No 23 Tahun 1997 ditetapkan dalam Pasal 3 yang berbunyi :

"Pengelolaan lingkungan hidup yang diselenggarakan dengan asas tanggungjawab negara, asas berkelanjutan, dan asas manfat bertujuan untuk mewujudkan pembangunan berkelanjutan dan yang berwawasan lingkungan hidup dalam rangka penaggungan berkelanjutan yang berwawasan lingkungan hidup dalam rangka pembangunan manusia Indonesia seutuhnya dan pembangunan masyarakat Indonesia seluruhnya yang telah beriman dan betaqwa kepada Tuhan Yang Maha Esa”.

Jika kita lihat bahwa pada pasal 3 dan pasal 4 pada hakekatnya merupakan substansi dari kebijakan pengelolaan lingkungan dan sekaligus sebagai bagian dari substansi hukum lingkungan pada dasarnya bertujuan 
menciptakan kualitas lingkungan hidup yang sehat, indah bersih dan aman. Dengan demikian, kualitas lingkungan hidup harus tampil sebagai parameter keberhasilan pembangunan di Indonesia.

Dalam pembangunan yang berwawasan lingkungan dan berkelanjutan, ukuran ekonomi yang berupa tingginya pendapatan perkapita, bukan hanya satu satunya tolak ukur atau parameter keberhasilan pembangunan, tetapi masih harus ditambahkan dengan ukuran ukuran lainya, seperti kesehatan, pendidikan, dan kualitas lingkungan. Pembangunan yang hanya mementingkan keuntungan ekonomi umumnya akan mengakibatkan eksploitasi atau pemerasan terselubung terhadap sumber daya alam dan sumber daya manusia. Oleh karena itu, konotasi pembangunan (development) tidak lagi semata mata dilihat sebagai persoalan perbaikan (improvement) khusunya terhadap struktur ekonomi suatu masyarakat, misalnya terciptanya kemakmuran, tetapi juga mempersoalkan cara bagaimana kemakmuran itu dipikirkan, untuk kepentingan siapa dan kenapa. Dengan demikian, pertumbuhan (grownth) harus diukur berdasarkan membaiknya kualitas hidup.

Jika mengevaluasi terhadap keberhasilan pembangunan yang selama ini masih belum mamasukan parameter kualitas lingkungan hidup manusia, sehingga implementasi kebijakan dan hukum lingkungan sebagai istrumen pembangunan berwawasan lingkungan dan berkelanjutan masih ada pada fase rumusan dan sosialisasinya, belum sampai pada fase penerapan yang sesunggunhnya. Hal ini tampak bahwa dari berbagai pelaksanaan pembangunan, yang paling banyak bersentuhan dengan kepentingan lingkungan, khusunya bidang ekonomi dan industri, yang hanya mengedepankan keberhasilan pembangunan fisik, seperti peningkatan jumlah pabrik, gedung dan jembatan yang dibangun, sedangkan dampak negatif pembangunan terhadap lingkungan hidup seringkali takterpedulikan. Hingga saat ini masih sering terjadi kasus pencemaran lingkungan yang disebabkan oleh kegiatan industry bahkan 
sudah sering pula beberapa industri diajukan ke pengadilan karena dituduh sebagai pihak yang mencemarkan lingkungan. Tetapi bagai mana kebijakan pemerintah dalam menyelesaikan kasus pencemaran lingkungan tersebut dalam koteks hukum lingkungan.

Dalam konteks hukum lingkungan jika telah terjadi kasus maka penyelesaianya kasus lingkugan sebagai salah satu wujud penegakan hukum lingkungan dapat dilakukan melalui pengadilan dan diluar pengadilan. Penyelesaian kasus memalui proses dan mengikuti tata cara atau prosedur hukum sebagai mana yang telah ditetapkan dalam hukum antara, sedangkan penyelesaian kasus diluar pengadilan berdasarkan kesepakatan dari kedua belah pihak yang bersengketa dengan model konsilisi, mediasi, dan arbitasi.

Praktek penyelesaian kasus lingkungan yang sering terjadi selama ini, selalu mengutamakan pertimbangan ekonomi dari pada pertimangan kualitas lingkungan (ekologis); dan selalu memunculkan alasan pertimbangan yang memanfatkan kegiatan industri dengan alasan yang macam mana, diantaranya indunstri merupakan kebijakan nasional untuk menyediakan lapangan kerja, penambahan devisa negara dan sebagainya. Walaupun dalam praktek tidak jarang pemaafan industri yang mencemarkan itu lantaran pemilik industri tersebut kebetulan adalah orang orang yang dekat dengan pemilik kekuasaan negara ini atau kaum kapitalis yang diuntungkan dalam srtrategi pembanagunan. Misalnya, dalam kasus tercemarnya Kali Surabaya akibat tumpah residu PT Mekabox Gresik, Jawa Timur tahun 1995, akibat kelalaian salah seorang karyawannya, pemeriksaan terhadap karyawan tersebut berjalan sangat lancar, sampai pada Putusan Pengadilan, sehinga memunculkan kesan bahwa penegakan hukum (lingkungan) di Indonesia hanya efektif terhadap orang kecil, sedangkan yang berduit dan orang orang yang berada di dekat pusat pusat kekuasaan, penegakan hukum lingkungan masih mandul. 
Oleh katrena itu, segala dapak dan akibat negatif yang diakibatkan oleh kebijakan yang menomorsatukan ekonomi, termasuk industri selama yang ada di Indonesia, tidak dimasukkan dalam parameter guna mengevaluasi keberhasilan pembangunan . konsekwensinya, pembangunan yang menimbulkan dampak negatif pada lingkungan hidup dianggap sebagai konsekwensi logis dari suatu proses pembangunan.

Dalam konteks pembangunan yang berwawasan lingkungan dan berkelanjutan sudah saatnya angapan diatas, ditinggalkan, sehingga kebijakan dan hukum lingkungan ditingkat perumuasan sampai pada tingkat pelaksanaanya dan implementasinya itu konsisten, sebab jika tidak, kualitas lingkungan Indionesia akan terus merosot seta hukum lingkungan secara materiil tidak harus ditinggalkan atau menunggu terjadinya suatu kasus yang menyebabkan timbulnya malaptaka kepada masyarakat atau merugikan kehidupan umat manusia.

\section{PENUTUP}

\section{Kesimpulan}

a. Kebijakan hukum lingkungan setelah diimplementasikan sebagai instrumen pembangunan berwawasan lingkungan, masih baru sampai pada fase dan formulasi materi belum sampai ada peaksanaan yang sesungguhnyaa, yang telah mengedepankan terciptanya kualitas lingkungan hidup, sebab pertimbangan kualitas lingkungan hidup acapkali dikalahkan oleh pertimbangan ekonom.

b. Kebijakan dan hukum lingkungan sudah dilaksanakan dengan benar. Hukum lingkungan di Indonesia sudah diaplikasikan sebagai instrumen pembangunan yang berwawasan lingkungan dan berkelanjutan. 


\section{DAFTAR PUSTAKA}

\section{A. Literatur}

Amsyari, Fuat, Membangun Lingkungan Sehat Menyambut 50 Tahun Indonesia Merdeka, Airlangga Universitas, Press. 1996

Admosudirdjo S.P. Dasar Dasar Administrasi Negara Jakarta : Ghalia Indonesia. 1990

Anonymous Bumi Wahana, Strategi Menuju Kehidupan yang Berkelanjutan, Jakarta PT Gramedia Pustaka Utama, Caring The Earth, Astrategy for Sustainable Living. 1993

Hardjosumantri, K., Hukum Tata Lingkungan, Yogyakarta: Gadjah Mada Universitas Press. 1994

Hadjon, M.P.dkk Pengantar Hukum Adinistrasi Indonesia (Intruduction to the Administrative Law) Yogyakarta: Gajah Mada University Press.1994

Indroharto,Usaha Memahami Undang Undang Tentang Peradilan Tata Usaha Negara, Jakarta, Pustaka Sinar Harapan. 1991.

Ismani, HP. Dasar Dasar Ilmu Pemerintahan Malang, IKIP Malang. 1996.

Purbopranoto, K. Beberapa Catatan Hukum Tata Pemerintahan dan Peradilan Adiministrasi Negara, Bandung Alumni. 1978.

Rangkuti, SS. Hukum Lingungan dan Kebijaksanaan Lingkunga Nasional, Suabaya : Airlangga Univesitas Press. 1996.

Soetaryono, R. Kebijakan, Hukum dan Peraturan Perundang Undangan di Bidang Lingkungan Hidup. 1998.

Wahab,A.S. Esensi Nilai dalam Kebijakan Perbincangan Teoritikal, dalam Achmadi, dkk., Kebijakan Publik dan Pembangunan, Malang IKIP Malang. 1994. 